\title{
MAPPING THE CAPACITY OF THE MOSQUE IN SPATIAL REVIEW IN EAST BOGOR SUB-DISTRICT
}

\author{
Mohamad Mahfudz ${ }^{1}$, Diah Kirana Kresnawati ${ }^{2}$, Eky Palahudin ${ }^{3}$ \\ Geodesy Engineering, Universitas Pakuan \\ E-mail : m.mahfudz59@gmail.com
}

\begin{abstract}
The increasing awareness of Muslims about Islam encourages them to participate in activities carried out by mosque administrators, this has an impact on the capacity of the mosque space. This study aims to determine the distribution of mosques and their capacities based on the population in East Bogor Sub-District. Data collection is done by using spatial data to support decision making to increase efficiency and time accuracy by using the buffering method. Where the buffer is to determine the optimal radius assuming distances of $100 \mathrm{~m}, 250$ m, $500 \mathrm{~m}$, and $1000 \mathrm{~m}$. The results showed that in East Bogor District there were 73 mosques and the capacity of the mosques was 33.72\% of the total population of 106,029 people.
\end{abstract}

Keywords: East Bogor Sub-District; Mosque Capacity; GIS

\section{A. INTRODUCTION}

A place of worship is an important religious facility for religious believers in a place. Apart from being a symbol of the "existence" of religious adherents, a place of worship is also a place for broadcasting religion and a place for worshiping. The mosque is a multi-functional place of worship. A mosque is not a place of worship that is devoted to worship alone, but all positive and beneficial activities for the people are often initiated by mosques. Prayers that are performed in congregation at a mosque in itself signify the mosque as an important institution in Islam as Muslims must attend and congregate at the mosque five times a day, day and night. The mosque also functions as a center for the formal teaching of religious education. In addition, the mosque also serves the commemoration of important religious events as well as an administrative center for mosque administrators (Fauzi \& Abd, 2015). Mosques play an important role by serving comprehensive functions for society including education, culture and politics (Maimunah Abdul Aziz et al., 2016). The mosque is also a center of civilization that is not just a center of recitation because residents can gather and stay in touch so as to enlighten, prosper and unite the people. Moreover, mosques may play an important role in preparing children for academic success. Children who attend mosque school do better on tests than elsewhere (Burde et 
al., 2015). East Bogor Subdistrict has up to now approximately 73 mosques, considering the population growth, especially those who are Muslims, always increase every year, especially the increase in mosque and prayer facilities which positively encourages Muslim tourists to enter or visit mosques (Battour et al., 2011), this will indirectly affect the increasing number congregation of the mosque. This resulted in the mosque's capacity not being able to accommodate the number of worshipers. Until now, the available information regarding mosque data in Bogor City is only limited to addresses, there is no spatial description of the information on the existence of mosques. Data collection systems, analysis and spatial data to support decisions to increase time efficiency and accuracy are used the Geographic Information System (GIS) method. With GIS, it is expected to be able and facilitate the decision making process and the resulting solution is the most optimal solution.

Based on government regulations No. 2 of 1995 and Inmendagri No. 30 of 1995 dated 24 August 1995 concerning Changes in the Territorial Boundary of the Regional Municipality of Tk. II Bogor and the Regional District Tk. II Bogor, East
Bogor SubDistrict with an area of 1,015 hectares, consists of 6 sub-districts of 318 RT and 59 RW. The villages in East Bogor Sub-District can be seen in the table 1 below:

Table 1. Sub-District of East Bogor

\begin{tabular}{clc}
\hline No & \multicolumn{1}{c}{ Name of Village } & Area \\
\hline 1 & Baranangsiang Village & $235 \mathrm{Ha}$ \\
2 & Sukasari Village & $48 \mathrm{Ha}$ \\
3 & Katulampa Village & $491 \mathrm{Ha}$ \\
4 & Tajur Village & $45 \mathrm{Ha}$ \\
5 & Sindangsari Village & $90 \mathrm{Ha}$ \\
6 & Sindangrasa Village & $106 \mathrm{Ha}$ \\
\hline
\end{tabular}

With the northern borders bordering Bogor District, in the east bordering Sukaraja District, Bogor Regency, in the west bordering South Bogor District and Central Bogor District, in the south bordering Ciawi District, Bogor Regency (Bapeda Kota Bogor, 2014). The total population of East Bogor District in 2017 was 106,029 people. The population growth rate in East Bogor District is $1.23 \%$ with a population density rate per $\mathrm{km} 2$ of 10,446 people. The population level based on gender was 53,471 male and 52,558 female. The percentage of 93\% of the population of East Bogor SubDistrict is Muslim. The number of population Village in East Bogor is as follows: 
Table 2. Total Population Village

\begin{tabular}{|c|c|c|c|c|c|c|}
\hline \multirow[t]{2}{*}{ No } & \multirow[t]{2}{*}{ Village } & \multirow{2}{*}{$\begin{array}{l}\text { Area } \\
\left(\mathrm{km}^{2}\right)\end{array}$} & \multirow{2}{*}{$\begin{array}{l}\text { Population } \\
2016\end{array}$} & \multirow{2}{*}{$\begin{array}{l}\text { Population } \\
2017\end{array}$} & \multicolumn{2}{|c|}{$\begin{array}{l}\text { Population Density } \\
\qquad\left(\mathrm{Km}^{2}\right)\end{array}$} \\
\hline & & & & & 2016 & 2017 \\
\hline 1 & Sindangsari & 0,9 & 10707 & 10817 & 11897 & 12019 \\
\hline 2 & Sindangrasa & 1,06 & 15798 & 16172 & 14904 & 15257 \\
\hline 3 & Tajur & 0,45 & 6608 & 6586 & 14684 & 14636 \\
\hline 4 & Katulampa & 4,91 & 33484 & 34515 & 6820 & 7030 \\
\hline 5 & Baranangsiang & 2,35 & 27324 & 27290 & 11627 & 11613 \\
\hline 6 & Sukasari & 0,48 & 10816 & 10649 & 22533 & 22185 \\
\hline & Total & 10,15 & 10816 & 106029 & 20319 & 10446 \\
\hline
\end{tabular}

The establishment of places of worship is regulated in the Joint Regulation of the Minister of Religion and the Minister of Home Affairs No. 9 and No. 8 of 2006. Article 13 paragraph 1 states that the construction of houses of worship must be based on real considerations and needs based on the composition of the kelurahan / village area. The construction was 53,471 male and 52,558 female. The percentage of 93\% of the population of East Bogor SubDistrict is Muslim (Bapeda Kota Bogor, 2014). Houses of worship must also meet the administrative and technical requirements for buildings mentioned in Article 14 paragraph 1. Furthermore, in paragraph 2, some special requirements in the construction of places of worship are explained. First, the list of names and cards of users of places of worship must be at least 90 people, which is legalized by local officials. Second, the support of the local community must be at least 60 people authorized by the lurah or village head. Third, there must also be a written recommendation from the head of the district / city religious affairs department head. Finally, a written recommendation from the district / city FKUB (Forum for Religious Harmony) (Kementrian D, 2006). Worship facilities are a means of life to fill spiritual needs that need to be provided in a planned housing environment other than according to stipulated regulations, worship facilities are planned according to the wishes of the community itself with the number of residents who adhere to their respective religions. A regulated planning approach is to estimate the population and type of religion and belief and then plan the allocation of land and location for buildings of worship according to planological and religious demands (BSN, 2019).

GIS (Geographic information system) is a type of software that can be used for the input, storage, manipulation, display, and output of information and its 
attributes related to the positions on the earth's surface and GIS is more scientific and efficient, in performing data analysis and spatial exploration functions (QiongLin et al., 2020).It is being done through the capabilities of GIS on providing an ease monitor-ing, and detecting routes (Rezaei et al., 2020). GIS software allows users to view spatial data in a suitable format. the process of interpreting spatial data becomes easier and simpler (Luqun et al., 2002). Spatial correlation and autocorrelation play a significant rolein spatial modeling (Shariati et al., 2020). Geographical Information System(GIS) to map and visualize buildings and their occupants (Afnarius et al., 2020). By utilizing geographic information systems, in this study, the analysis of determining the shortest route for waste transportation is using Network Analysis and the Graph method.

\section{B. MATERIALS AND METHODS}

This research methodology uses hardware, namely a laptop, handheld gps Garmin 78s, camera. While the software used in this research is BaseCamp which is used for the process of downloading GPS data, the global mapper is used for the export and conversion process of GPS data, and ArcGis 10.1 is used for the process of editing, plotting attribute data, analyzing and making distribution maps of mosques located in the Sub-District East Bogor. Buffering functions to determine the optimal buffer radius to detect the distribution and capacity of mosques. In the next step, the detected mosques are combined into the map and corrected geometrically, topologically, and semantically (Liu et al., 2015). While the research steps can be seen in Figure 1 below: 


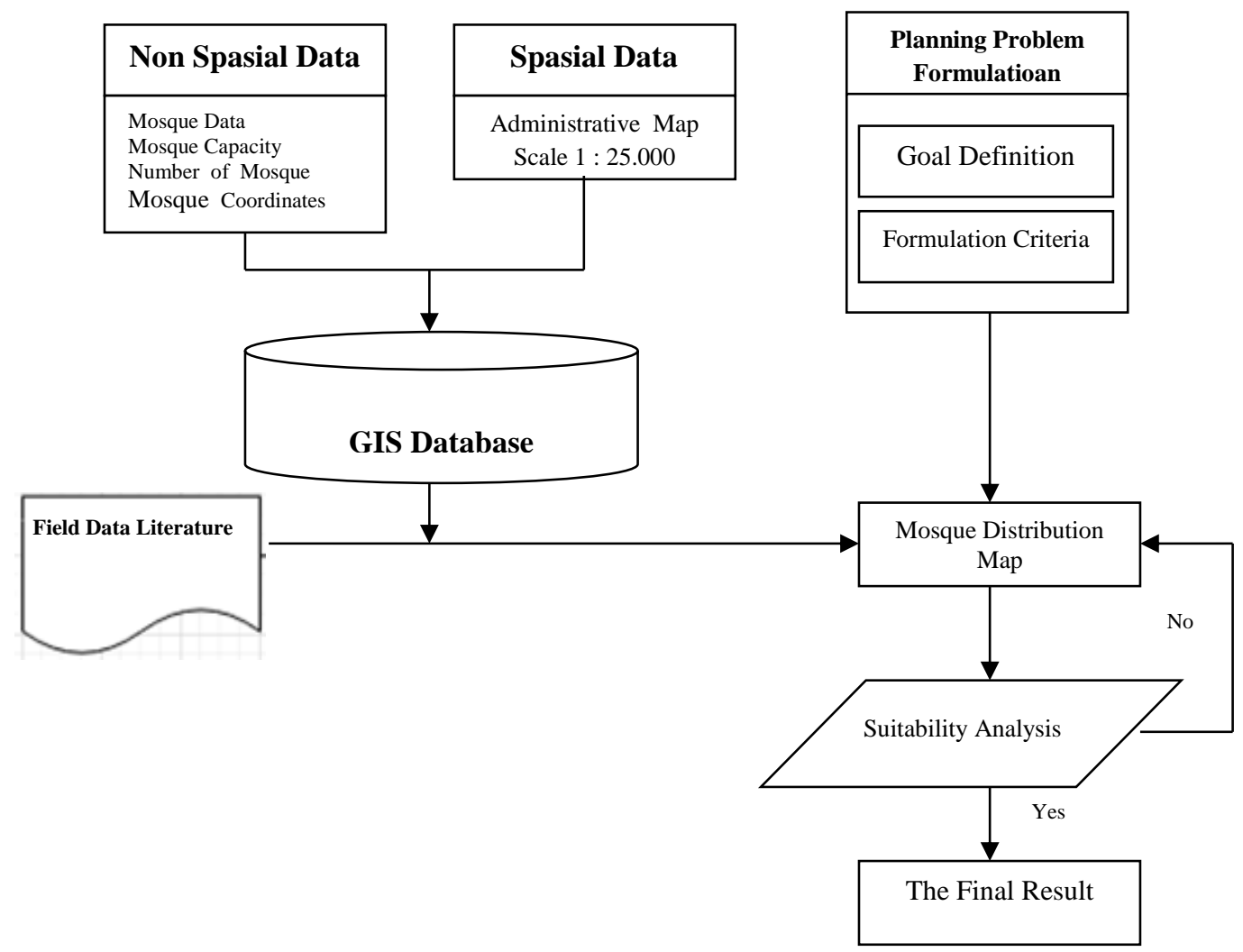

Figure 1. Framework Research

The process of implementing this research, apart from conducting a study of existing literature, also carried out field observations to determine the distribution conditions of the existing mosques. Data processing by downloading and exporting data from GPS using basecamp format $(\wedge$ .gpx), in order to obtain the coordinates of the distribution of mosques in the format (^ .shp), buffering analysis is carried out to determine the reach of the community to access the mosque.

\section{RESULTS AND DISCUSSION}

Based on the survey results in the field, it was found that the distribution of mosques in each kelurahan has a total of 73 mosques. From the total data, the highest number of mosques is in Katulampa Village, as many as 27 mosques, while the least number is in Sukasari Village, there are only 3 mosques. The details can be seen in table 3. From the existing mosque data, it is processed using Arcgis 10.3 software. This process produces a map of the distribution of mosques in each subdistrict in East Bogor Sub-District. The map of the distribution of mosques from each village can be seen in Figure 2. 
Table 3. Distribution of Mosques in Each Village

\begin{tabular}{clc}
\hline No & Name of Village & $\begin{array}{c}\text { Ammount } \\
\text { of Mosque }\end{array}$ \\
\hline 1 & Baranangsiang & 18 \\
2 & Sukasari & 3 \\
3 & Katulampa & 27 \\
4 & Tajur & 6 \\
5 & Sindangsari & 8 \\
6 & Sindangrasa & 11 \\
\hline & Total Number & 73 \\
\hline
\end{tabular}

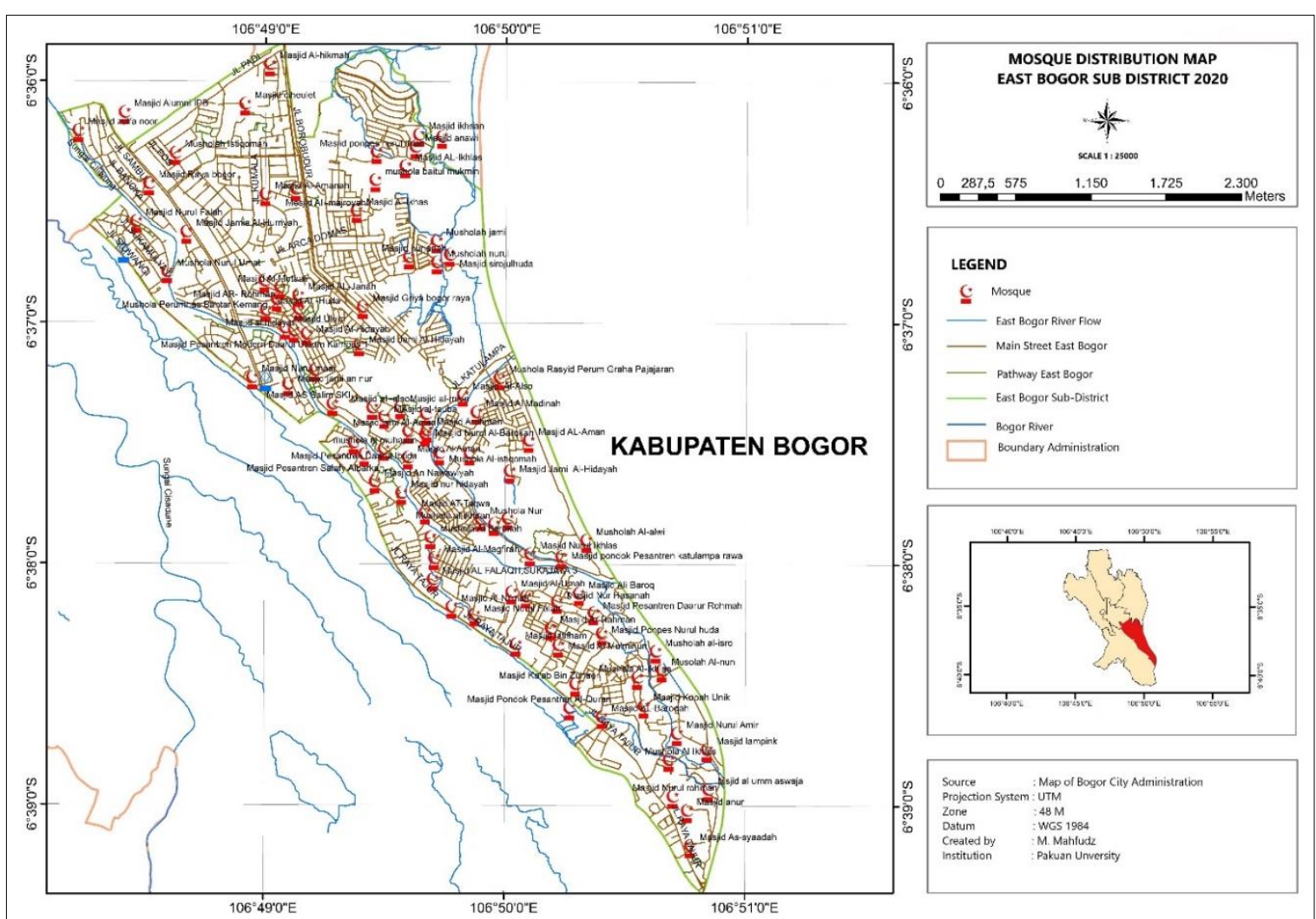

Figure 2. Distribution of Mosques in Each Village

Calculation of mosque capacity and radius of construction of mosques

The calculation of the capacity of mosques in each village is based on the equation:

$\mathrm{KMi}=\mathrm{JKM} / \mathrm{JP} \times 100 \%$

KMi: Capacity of the Mosque

JKM: Total Capacity of the Mosque JP: Total Population
Based on the National Standardization Agency for SNI 031733-2004, the establishment of places of worship in urban areas where the radius of the farthest reaches of the community is $1,000 \mathrm{~m} 2$. In this study, it is assumed that the radius of the community to be able to access the 
mosque is grouped into 4 categories, namely $100 \mathrm{~m} 2,250 \mathrm{~m} 2,500 \mathrm{~m} 2$, and the farthest is $1,000 \mathrm{~m} 2$. Based on these 4 categories, a buffering analysis was carried out of each mosque building in all villages in East Bogor Sub-District. The map of buffering results can be seen in the image below:

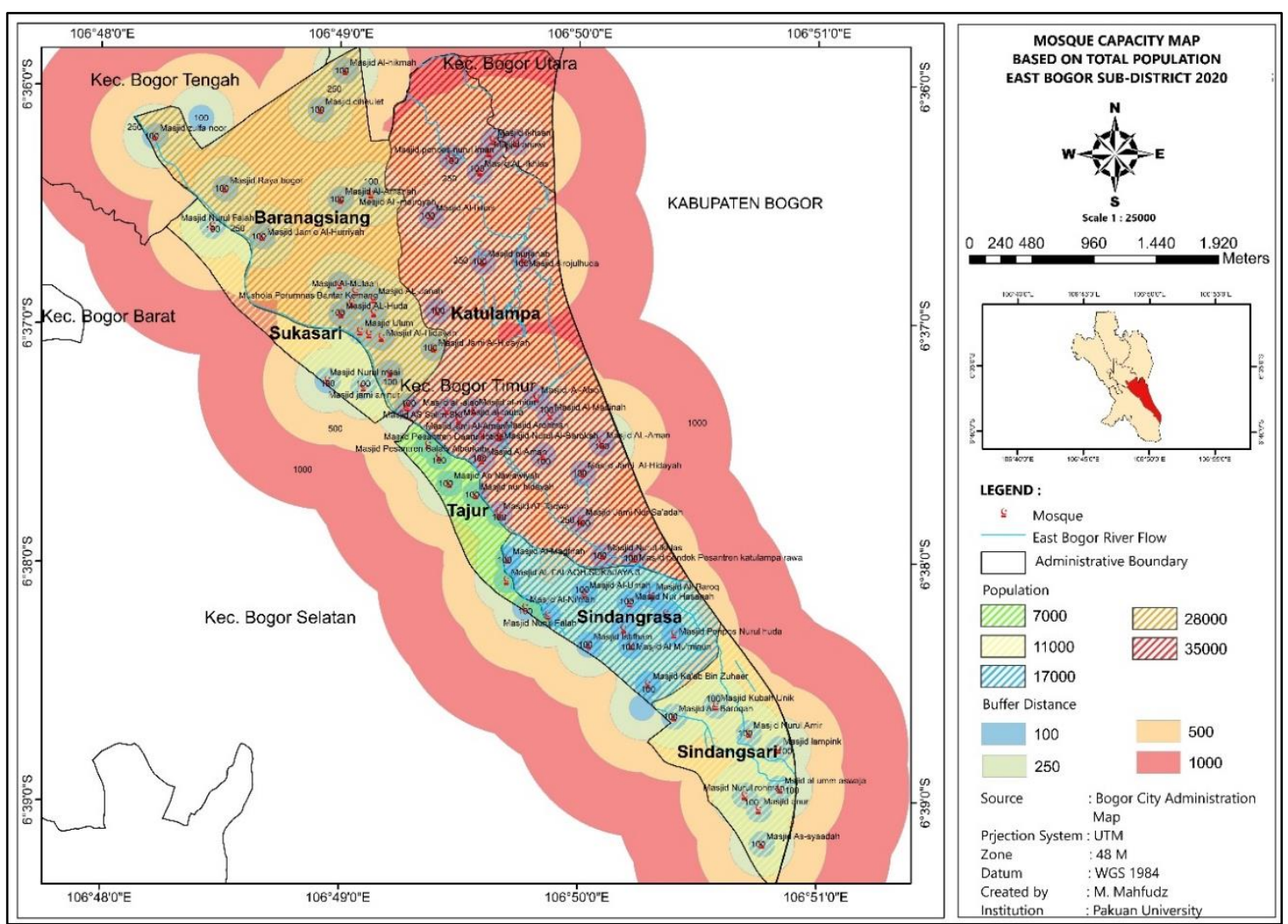

Figure 3. Mosque Capacity Map in East Bogor Sub-District

\section{CONCLUSIONS}

Based on the analysis in this study, it can be concluded that the geographic information system makes it easy to map and analyze the capacity of mosques. From the buffering analysis, all mosques in East Bogor District in terms of distance have met the criteria that have been set based on SNI 03-1733-2004 rules, namely $1000 \mathrm{~m} 2$ the farthest distance from each mosque. The capacity of all mosques in Barangsiang Kelurahan can accommodate $56.34 \%$ of worshipers, Kelurahan Katulampa can accommodate $33.50 \%$ of worshipers, Kelurahan Sindangrasa is able to accommodate $26.67 \%$ of worshipers, Kelurahan Sindangsari is able to accommodate $21.38 \%$ of worshipers. Kelurahan Sukasari is able to accommodate $21.72 \%$ of worshipers, while Kelurahan Tajur is 
able to accommodate $42.70 \%$ of worshipers.

\section{E. ACKNOWLEDGMENTS}

The author would like to thank the Bogor City Government, the East Bogor Sub-District Apparatus and the Village Apparatus in the East Bogor Sub-District for the assistance provided and allowing the author to access data in the Village to support this research and for the recommendations given by friends to discuss and participate in this research.

\section{F. REFERENCES}

Afnarius, S., Syukur, M., Ekaputra, E. G., \& Parawita, Y. (2020). Development of GIS for Buildings in the Customary Village of Minangkabau Koto Gadang, West Sumatra, Indonesia. 1-15.

Bapeda Kota Bogor. (2014). Bab 2 Gambaran Umum Wilayah. Laporan Akhir Layanan Persampahan Kota Bogor, 1-33.

Battour, M., Ismail, M. N., \& Battor, M. (2011). The impact of destination attributes on Muslim tourist's choice. International Journal of Tourism Research, 13(6), 527-540. https://doi.org/10.1002/jtr.824

BSN. (2019). Rekap SNI yang Telah Diberlakukan Secara Wajib Status : Desember 2019 Daftar SNI Yang Telah Diberlakukan Wajib.

Burde, D., Middleton, J. A., \& Wahl, R. (2015). Islamic studies as early childhood education in countries affected by conflict: The role of mosque schools in remote Afghan villages. International Journal of Educational Development, 41, 7079.

https://doi.org/10.1016/j.ijedudev.2 014.10.005

Fauzi, M., \& Abd, B. (2015). Performance Measurement Model of Mosques. Procedia Economics and Finance, 31(15), 26-35. https://doi.org/10.1016/S22125671(15)01128-4

Kementrian D. (2006). Pedoman Pelaksanaan Tugas Kepala Daerah/Wakil Kepala Daerah Dalam Pemeliharaan Kerukunan Umat Beragama, Pemberdayaan Forum Kerukunan Umat Beragama, Dan Pendirian Rumah Ibadat. ITJEN Kemenag RI. http://itjen.kemenag.go.id/

Liu, C., Xiong, L., Hu, X., \& Shan, J. (2015). A progressive buffering method for road map update using OpenStreetMap data. ISPRS International Journal of GeoInformation, 4(3), 1246-1264. https://doi.org/10.3390/ijgi403124 6

Luqun, L., Jian, L., \& Yu, T. (2002). ACSG Table of contents Table des matières Authors index Index des auteurs The Study on Web GIS Architecture Based on JNLP. Dbms, 1-6.

Maimunah Abdul Aziz, Mansor Ibrahim, Puteri Shireen Jahnkassim, \& Alias Abdullah. (2016). Issues and Potential of Mosque as a Spiritual Tourism Destination in Malaysia. Proceedings of ISER 22nd International Conference, February, 8.

Qiong-Lin, L., Zhi-Ping, L., \& Si-Yi, C. (2020). Analysis of the Morphological Characteristics of Canton Postal ArchitecturalLayout from 1842 to 1949 on GIS. IOP 
Conference Series: Earth and Environmental Science, 525(1). https://doi.org/10.1088/17551315/525/1/012106

Rezaei, M., Nouri, A. A., Park, G. S., \& Kim, D. H. (2020). Application of geographic information system in monitoring and detecting the COVID-19 outbreak. Iranian Journal of Public Health, 49, 114116.

https://doi.org/10.18502/ijph.v49is
1.3679

Shariati, M., Mesgari, T., Kasraee, M., \& Jahangiri-rad, M. (2020). Spatiotemporal analysis and hotspots detection of COVID-19 using geographic information system (March and April, 2020). Journal of Environmental Health Science and Engineering, 18(2), 1499-1507.

https://doi.org/10.1007/s40201020-00565-X 